\title{
Night eating syndrome and emotional states in university students
}

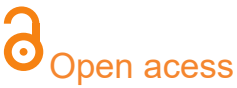

${ }^{1}$ Faculdade de Medicina do ABC (Santo André, SP, Brasil)

${ }^{2}$ Faculdade de Juazeiro do Norte (Juazeiro do Norte, CE, Brasil)

\section{Corresponding author:} ricardo.souto@fmabc.br

Manuscript received: August 2017 Manuscript accepted: November 2017 Version of record online: December 2017

\author{
Karina Morais Borges ${ }^{1,2}$, Francisco Winter dos Santos \\ Figueiredo', Ricardo Peres do Souto ${ }^{1}$
}

\begin{abstract}
Introduction: University students are exposed to many factors related to Night Eating Syndrome (NES), an eating disorder that may be associated with obesity.
\end{abstract}

Objective: To determine the prevalence of NES among students from a Brazilian university and evaluate the association of the syndrome behaviours with emotional, biological and environmental factors.

Methods: Cross-sectional study with 200 students from a private higher education institution located in the city of Juazeiro do Norte, Ceará, Brazil. NES was evaluated using the Night Eating Questionnaire (NEQ), considering the NEQ score $\geq 25$ as the cutoff value for indication of the syndrome. Depression, anxiety, and stress symptoms were assessed using the Depression Anxiety Stress Scales (DASS-21) questionnaire. Additional information was collected about the participants (gender, age, weight and height), the academic status (enrolled course, study period and year) and the employment status (whether the participant worked at least $4 \mathrm{~h}$ daily in addition to studying).

Results: 30 participants (15\%) presented NEQ score $\geq 25$, indicative of NES. There was no association between the NEQ score and the variables: gender, nutritional status, work, enrolled course, study period and academic year. There was an association between NEQ score and severity of depression $(p=0.0001)$, anxiety $(p=0.0001)$ and stress $(p=0.0218)$.

Conclusion: Evidence of a high prevalence of NES was found among Brazilian university students and an association between the behaviours of the syndrome with depressive, anxiety and stress symptoms was found.

Keywords: feeding and eating disorders, students, depression, anxiety, psychological stress 


\section{INTRODUCTION}

The magnitude of eating disorders has increased considerably, with a significant impact on public health ${ }^{1}$. Among these disorders, Night Eating Syndrome (NES), recently added to he Diagnostic and Statistical Manual of Mental Disorders (DSM-5) $)^{2}$, has received increasing attention due to its possible relationship with obesity ${ }^{3}$. NES is a condition characterized by nocturnal hyperphagia, disturbed sleep patterns, including recurrent episodes of awakening for food consumption, and morning anorexia ${ }^{4}$. Physiologically, there is a dysregulation of the circadian control of feeding with several changes in secretion profiles of leptin, insulin, melatonin, cortisol, and ghrelin ${ }^{5,6}$. Psychopathological factors, including mood disorders and the individual's level of stress, contribute significantly to the syndrome and should be considered for the most accurate diagnosis ${ }^{7}$.

NES was initially observed in obese individuals ${ }^{8}$, but also affects non-obese individuals ${ }^{9}$. Its estimated prevalence in the general population ranges from 1.1 to $1.5 \%{ }^{10,11}$. This prevalence is higher in some specific populations. The syndrome is found in 2 to $20 \%$ of the morbidly obese candidates for bariatric surgery ${ }^{12}$, in 8 to $25 \%$ of psychiatric patients $^{13}$, and in $8.6 \%$ of patients with sleep apnea ${ }^{14}$.

University students are exposed to several factors

\section{METHODS}

Cross-sectional study with university students from a private institution located in the city of Juazeiro do Norte, Ceará, Brazil. At the time of collection, the institution had 1890 students enrolled. The subjects were selected by non-probabilistic sampling, seeking a similar number of participants from all courses offered. Only duly enrolled students over 18 years old, who spontaneously agreed to participate, and signed the free and informed consent form were included. The final sample consisted of 200 students. The study followed the principles of the Helsinki Declaration and was approved by the Research Ethics Committee of Faculdade de Medicina do ABC (process 923.270).

Students evaluated were from the three morning courses ( $n=108)$ : Nutrition, Pharmacy, and Nursing, and the three evening courses $(n=92)$ : Accounting, Architecture, and Information Technology. The sample included students from the first to the fourth (last) year.

Data collection took place between March and June 2015, and two validated self-administered questionnaires were used: Night Eating Questionnaire (NEQ) ${ }^{25}$, adapted to Portuguese ${ }^{26}$, to indicate NES behaviours; Depression Anxiety Stress Scales (DASS-21) ${ }^{27}$, adapted to Portuguese ${ }^{28}$, to identify signs of depression, anxiety, and stress; and a questionnaire for the variables gender, age, weight, height, course enrolled, academic year, and study period. In this supplementary instrument, it was also investigated whether the participant had a job out of school hours and the number of hours worked per day. Regarding this variable, students were divided in two groups: working four or more hours a day in addition to studying and not working or working less than four hours a day.

NEQ presents 14 Likert-type questions. Each question has five possibilities of response ( $0-4$ points), that could favour NES development. The transition from late adolescence to early adulthood is a critical time for adopting inadequate eating patterns ${ }^{15}$. Consequently, they have a high frequency of eating disorders, particularly those involving compulsive behaviors ${ }^{16}$. In addition, some of the syndrome components are common among college students. Young adults have the highest food intake at night compared to other age groups ${ }^{17}$. Difficulties in sleep are frequent among university students ${ }^{18}$. Finally, demands of academic life and the uncertainty of the approaching professional life impose an important emotional burden on these young people, resulting in stress, depression, and anxiety ${ }^{19}$.

In fact, recent articles suggest that the prevalence of NES in college students may be higher than the prevalence in the general population, ranging from 1.24 to $9.5 \%{ }^{20-24}$. These surveys were conducted among students of different nationalities, but not among Brazilian students. Considering the relevant differences in academic life between countries, the present study aimed to determine the prevalence of Night Eating Syndrome among university students from a higher education institution in Brazil and to evaluate the association of syndrome behaviours with emotional, biological, and environmental factors in this population.

resulting in a total score ranging from 0 to 56 . Estimation of NES prevalence was based on NEQ scores equal to or greater than $25^{29}$.

The DASS-21 questionnaire consists of a set of three subscales of 7 Likert-type questions with four possible answers (0-3 points). Each subscale evaluates one of three emotional domains: depression, anxiety, and stress. The subjects were stratified into three categories of intensity considering standardised score ranges ${ }^{30}$. For the depression domain, the scores ranged from: 0 to 13 (normal and mild), 14 to 20 (moderate), and 21 to 42 (severe and extremely severe). For the anxiety domain the scores ranges were: 0 to 9 (normal and mild), 10 to 14 (moderate), and 15 to 42 (severe and extremely severe). For the stress domain the scores ranges were: 0 to 18 (normal and mild), 19 to 25 (moderate), and 26 to 42 (severe and extremely severe).

Variables of sex, nutritional status, work, enrolled course, and academic year, which composed the profile of the studied population, were presented by means of absolute and relative frequency. Quantitative variables age and NEQ score were not in normal distribution (Shapiro-Wilk test, $p$ $<0.05$ ) and were presented by median and $25 \%$ and $75 \%$ percentiles, respectively, for profile characterization, and by medians and confidence interval medians to evaluate the differences of the scores according to the characteristics of the profile. Differences between the variables were analyzed by Mann-Whitney test for variables with two groups, and by Kruskal-Wallis test for variables with more than two groups. The association between the variables from the population profile and the severity of anxiety, depression, and stress, assessed by DASS-21, was evaluated by the Chi-square test. The level of significance was $95 \%$. The statistical program used was Stata 11.0. 


\section{RESULTS}

Two hundred university students from all the courses offered by the educational institution analysed were evaluated (Table 1). Participants were mostly female $(65.0 \%)$, and the median age was 21 years. Regarding nutritional status, the majority were eutrophic $(68.5 \%)$. The proportion of students working at least four hours per day was $54.0 \%$. Considering only students enrolled in the evening period, this proportion is higher
(77.2\%). Most participants had low levels (normal or mild) of depression (57.5\%), anxiety $(70.5 \%)$, and stress $(93.0 \%)$.

The median NEQ score for all subjects was 17 (Table 1). Of those interviewed, 30 students (15.0\%) presented NEQ scores greater than or equal to 25 . Of these, seven subjects $(3.5 \%$ of the total) had a score of 30 or higher.

Table 1: Sex, nutritional status, work, age, NEQ score and DASS-21 domains of assessed college students. Juazeiro do Norte, Ceará, Brazil.

\begin{tabular}{|c|c|c|c|}
\hline Variables & $\begin{array}{c}\text { General } \\
(200)\end{array}$ & $\begin{array}{c}\text { Morning } \\
(108)\end{array}$ & $\begin{array}{c}\text { Evening } \\
(92)\end{array}$ \\
\hline & & $\mathrm{n}(\%)$ & \\
\hline \multicolumn{4}{|l|}{ Sex } \\
\hline Male & $70(35,0)$ & $17(15,7)$ & $53(57,6)$ \\
\hline Female & $130(65,0)$ & $91(84,3)$ & $39(42,4)$ \\
\hline \multicolumn{4}{|l|}{ Overweight/Obesity } \\
\hline No & $137(68,5)$ & $82(75,9)$ & $55(59,8)$ \\
\hline Yes & $63(31,5)$ & $26(24,1)$ & $37(40,2)$ \\
\hline \multicolumn{4}{|l|}{ Work ( $\geq 4$ hours/day) } \\
\hline No & $92(46,0)$ & $71(65,7)$ & $21(22,8)$ \\
\hline Yes & $108(54,0)$ & $37(34,3)$ & $71(77,2)$ \\
\hline \multicolumn{4}{|c|}{ DASS-21 Score - Depression } \\
\hline Normal/Mild & $115(57,5)$ & $61(56,5)$ & $54(58,7)$ \\
\hline Moderate & $50(25,0)$ & $24(22,2)$ & $26(28,3)$ \\
\hline Severe/Extremely Severe & $35(17,5)$ & $23(21,3)$ & $12(13,0)$ \\
\hline \multicolumn{4}{|l|}{ DASS-21 Score - Anxiety } \\
\hline Normal/Mild & $141(70,5)$ & $76(70,4)$ & $65(70,7)$ \\
\hline Moderate & $33(16,5)$ & $18(16,7)$ & $15(16,3)$ \\
\hline Severe/Extremely Severe & $26(13,0)$ & $14(12,9)$ & $12(13,0)$ \\
\hline \multicolumn{4}{|l|}{ DASS-21 Score - Stress } \\
\hline Normal/Mild & $186(93,0)$ & $98(90,7)$ & $88(95,6)$ \\
\hline Moderate & $6(3,0)$ & $4(3,7)$ & $2(2,2)$ \\
\hline Severe/Extremely Severe & $8(4,0)$ & $6(5,6)$ & $2(2,2)$ \\
\hline \multicolumn{4}{|l|}{ Median (p.25 - p.75)* } \\
\hline Age & $21,0(19,0-24,0)$ & $21,0(19,0-24,0)$ & $21,0(19,5-24,0)$ \\
\hline NEQ Score & $17,0(14,0-20,5)$ & $16,0(14,0-20,0)$ & $17,0(14,5-22,0)$ \\
\hline
\end{tabular}

* p. 25 - p.75: Percentile 25 e $75 \%$, respectively.

There was no statistically significant association between the NEQ score of the students and the variables gender, nutritional status, work, study period, enrolled course, or academic year (Table 2).

Regarding emotional states (Table 3), students with higher levels of depression had significantly higher NES scores, both in the complete population and after stratification per study period (morning or evening). There was also a significant association between higher NEQ scores and higher levels of anxiety and stress, for the whole group of students as well as those attending morning classes.
Analysing the relationship between emotional states and other variables studied, there was greater depression among female participants in the complete population $(p=0.050)$ and among students in the morning who worked more than four hours a day $(\mathrm{p}=$ 0.039) (Table 4). It was also observed that the course in which the student is enrolled contributed significantly to the level of anxiety for those in the evening period $(\mathrm{p}=0.042)$ (Table 5). No significant association was found between stress levels and the variables gender, nutritional status, work, study period, enrolled course, or academic year (data not shown). 
Table 2: Association between sex nutritional status, work, study period, enrolled course, academic year with NEQ scores of university students. Juazeiro do Norte, Ceará. Brazil.

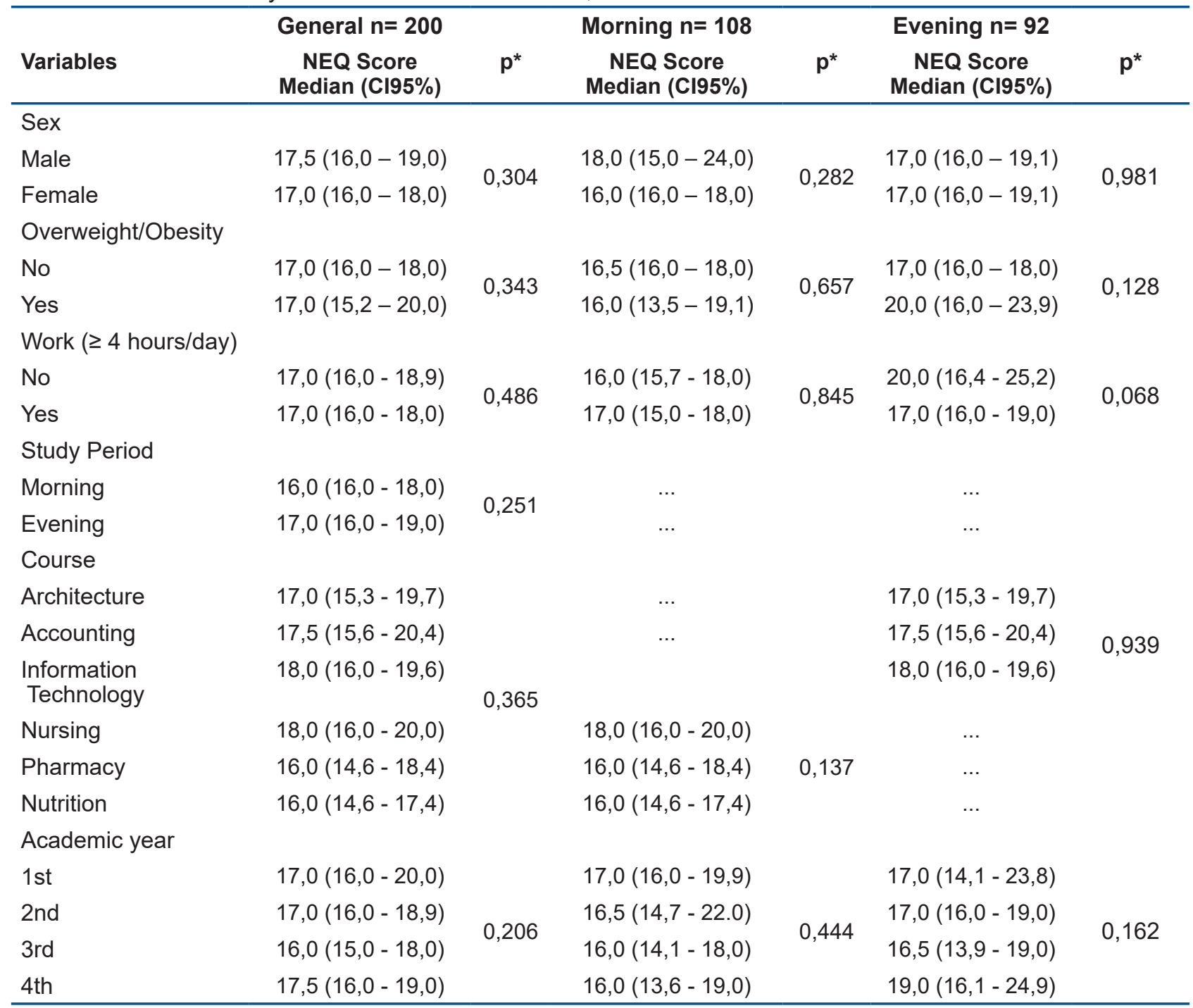

Cl 95\%: Confidence interval of 95\%; * Mann-Whitney Test (two groups); Kruskal-Wallis Test (tree or more groups);

... Does not aplly

Table 3: Association between NEQ score and severity of depression, anxiety, and stress in university students. Juazeiro do Norte, Ceará. Brazil.

\begin{tabular}{lccccc}
\hline DASS-21 Score & Variables & Normal/Mild & Moderate & $\begin{array}{c}\text { Severe/Extremely } \\
\text { Severe }\end{array}$ \\
& & & Median (Cl95\%) & $\mathbf{p}^{*}$ \\
\hline \multirow{3}{*}{ Depression } & General & $16,0(15,0-16,5)$ & $18,0(16,0-20,0)$ & $20,0(18,2-22,8)$ & 0,0001 \\
& Morning & $16,0(14,0-16,0)$ & $17,0(16,0-22,0)$ & $19,0(17,2-21,7)$ & 0,0026 \\
& Evening & $16,0(15,0-17,0)$ & $19,0(15,4-20,0)$ & $22,0(18,1-27,0)$ & 0,0047 \\
Anxiety & General & $16,0(15,0-17,0)$ & $18,0(16,0-20,0)$ & $20,0(18,4-24,0)$ & 0,0001 \\
& Morning & $16,0(14,0-16,0)$ & $18,0(16,0-24,7)$ & $19,5(17,8-24,5)$ & 0,0004 \\
& Evening & $17,0(15,1-18,0)$ & $19,0(14,3-20,8)$ & $20,0(17,0-25,9)$ & 0,0991 \\
Stress & General & $17,0(16,0-17,9)$ & $19,5(16,1-28,5)$ & $21,0(17,0-28,6)$ & 0,0218 \\
& Morning & $16,0(15,0-17,0)$ & $19,5(17,0-24,0)$ & $22,0(13,6-31,5)$ & 0,0431 \\
& Evening & $17,0(16,0-19,0)$ & $22,5(16,0-29,0)$ & $22,5(20,0-25,0)$ & 0,3185 \\
\hline
\end{tabular}

Cl 95\%: Confidence interval of 95\%; ${ }^{*}$ Kruskal-Wallis Test. 


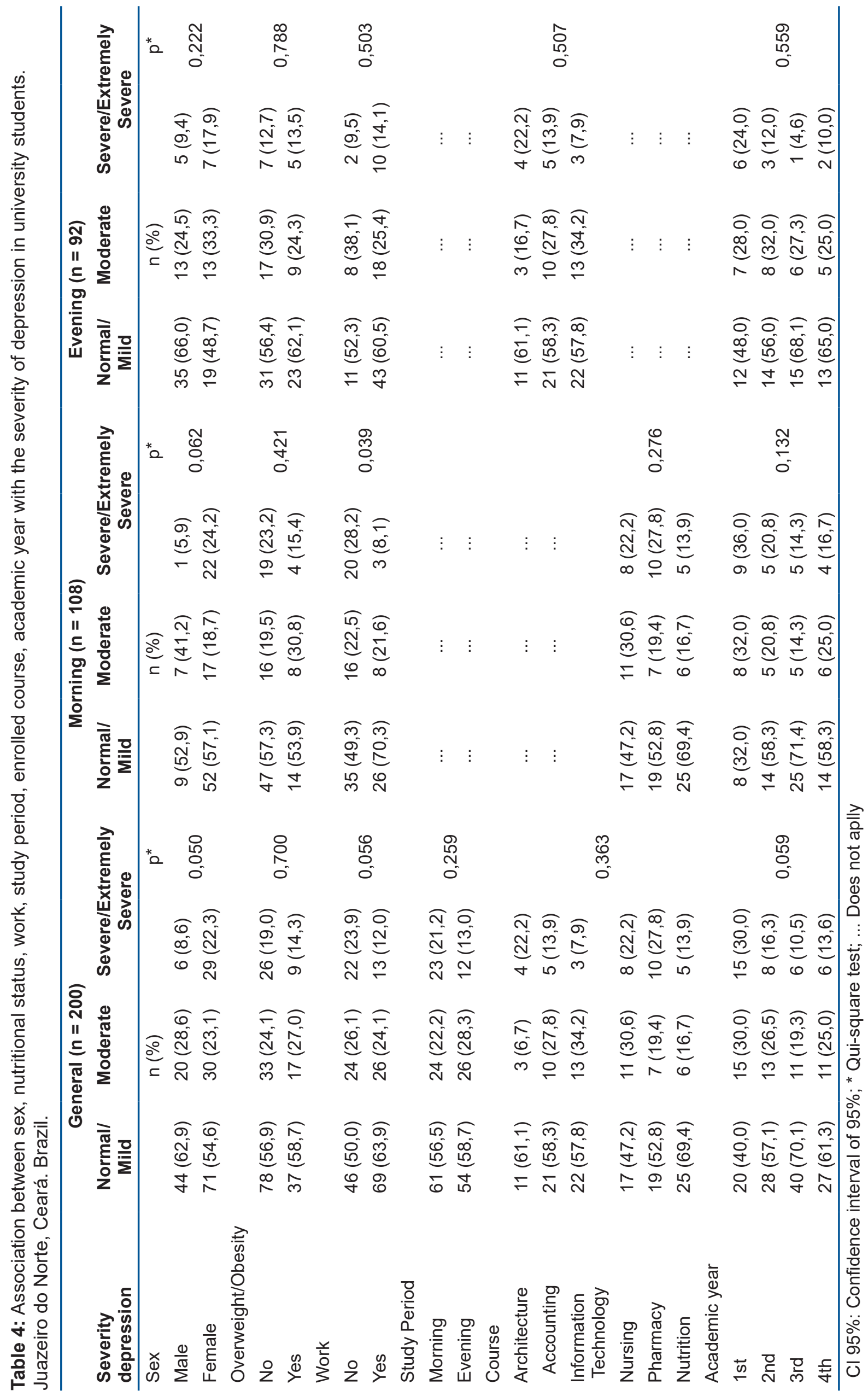




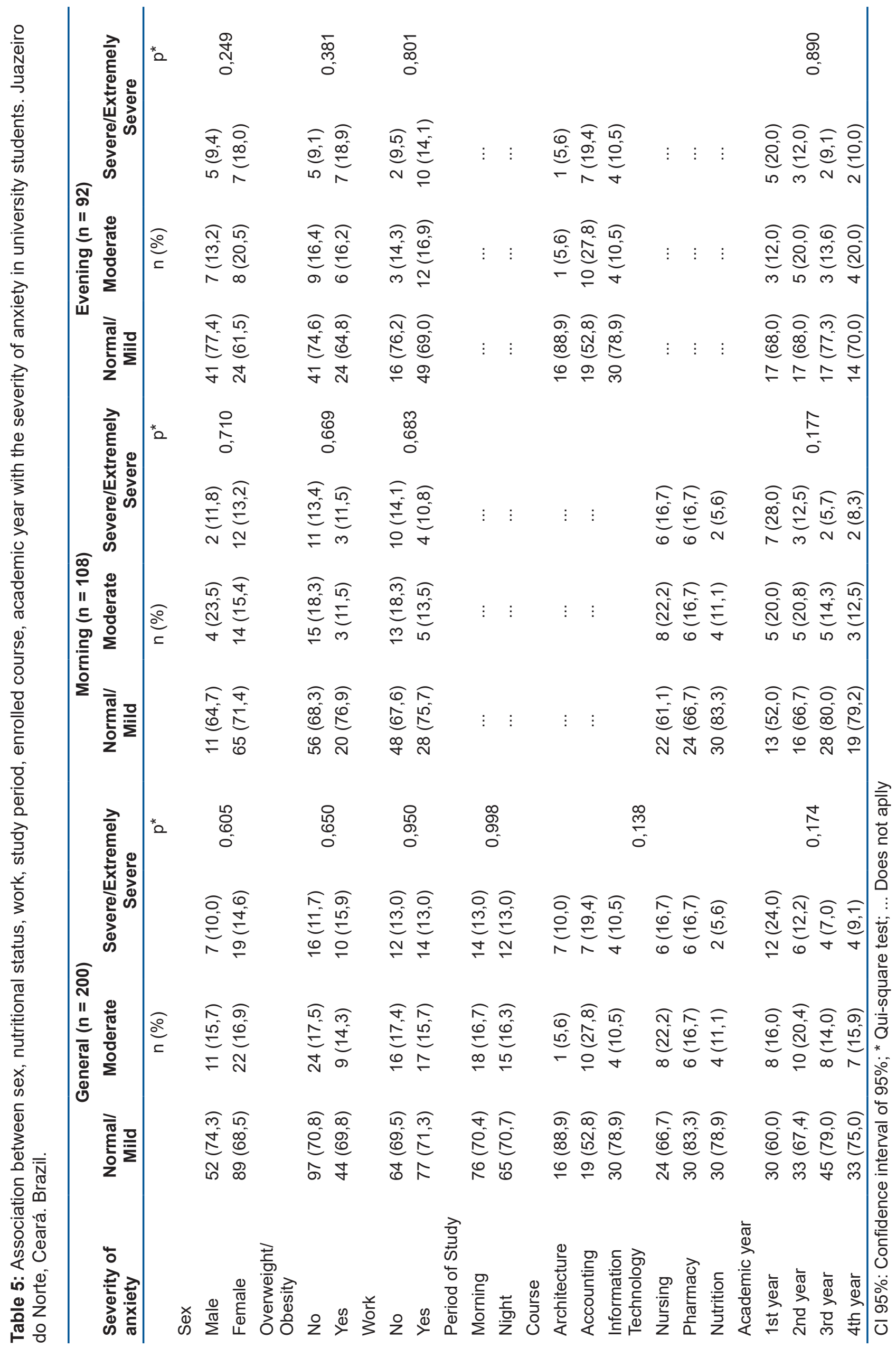




\section{DISCUSSION}

In this study, Night Eating Syndrome was evaluated in university students of a Brazilian higher education institution, and an association with the severity of depression, anxiety, and stress was found, as well as evidence for high prevalence of this condition.

In the analysed population, many students presented high NEQ scores. Values above the cut-off point (NEQ $\geq$ 25 ), indicating subjects possibly affected by the syndrome, were reached by $15.0 \%$ of the students. The second cut-off point (NEQ $\geq 30$ ), used for a greater diagnostic specificity of the syndrome, was reached by $3.5 \%$ of the students. Using the NEQ $\geq 25$ cut-off point, the prevalence found is about ten times higher than that estimated for the general population $^{10,11}$, and higher than the estimated prevalence for other populations of university students (Table 6).

Table 6: Prevalence of Night Eating Syndrome among university students based on the application of Night Eating Questionnaire (NEQ)

\begin{tabular}{|c|c|c|c|c|}
\hline & Number of participants & Country & $\mathrm{NEQ} \geq 25$ & $\mathrm{NEQ} \geq \mathbf{3 0}$ \\
\hline Runfola et al. $(2014)^{22}$ & 1.636 & USA & $2,0 \%$ & $0,5 \%$ \\
\hline Meule et al. (2014)21 & 666 & Germany & $1,24 \%$ & $0,3 \%$ \\
\hline Elsadek et al. $(2014)^{23}$ & 420 & Egypt & $5,8 \%$ & n.a. ${ }^{*}$ \\
\hline Nolan \& Geliebter $(2016)^{20}$ & 245 & USA & $2,0 \%$ & $0,0 \%$ \\
\hline Sevincer et al. $(2016)^{24}$ & 210 & Turkey & $9,5 \%$ & n.a. ${ }^{*}$ \\
\hline This study & 200 & Brazil & $15,0 \%$ & $3,5 \%$ \\
\hline
\end{tabular}

${ }^{*}$ n.a. $=$ not available

Most NES assessments among college students suggest that its prevalence is higher than in the general population. Only one study among German students ${ }^{21}$ found a proportion of NEQ scores $\geq 25$ within the range of 1.1 to $1.5 \%$, expected for the general population. Among North American students, two studies found 2.0\% NEQ scores above $25^{20,22}$. Studies conducted among Egyptian students $^{23}$ and Turks ${ }^{24}$ found, respectively, 5.8\% and 9.6\% of participants above this cut-off point. In this study, $15.0 \%$ of Brazilian students reached NEQ scores $\geq 25$.

The possibly of increased prevalence of NES among students, also suggested by this study, should be considered in health promotion actions and adequate eating habits for this group are essential.

The NEQ scores were significantly associated with the severity of symptoms of depression, anxiety, and stress, as determined by the DASS-21 questionnaire. This result confirms observations from other research groups using different instruments to determine psychological changes.

The association between NES and depressive symptoms, determined by the Beck Depression Inventory (BDI), was verified in several papers ${ }^{29,31,32}$, including one study with university students ${ }^{33}$. Importantly, not all studies found statistical significance for this relationship ${ }^{34}$, although there is more evidence supporting that subjects with NES present higher levels of depression. It is unclear whether depressive symptoms are the cause, characteristic, or consequence of the syndrome ${ }^{35}$.

Among the young people evaluated in this study, higher scores of depression were found in female participants and in students from the morning period who work more than four hours a day. The increase in depressive symptoms in these two cases, however, did not result in a significant increase in the corresponding NEQ scores.

In the initial description of NES, the importance of stressful events in the onset of the syndrome was suggested $^{8}$. More recently, the association of the syndrome with psychological stress was evaluated, mainly evaluated using the Perceived Stress Scale (PSS) ${ }^{29,31}$. This relationship was also confirmed in research carried out among university students ${ }^{36}$.

The levels of stress among the students evaluated in this study were low, only $4.0 \%$ of respondents presented severity of stress classified as severe or extremely severe by the DASS-21. It was not possible to identify factors related to stress other than NEQ score.

Regarding anxiety, some studies, using different instruments, pointed to an association with $\mathrm{NES}^{32,37,38}$. Although the level of anxiety of NES patients is greater than that of the general population, this emotional disorder is even more intense in the cases of subjects with NES periodic binge eating beyond the NES ${ }^{37}$.

Among the participants in this study, those who studied Accounting were more anxious in relation to the other evening courses, but this effect apparently did not result in an increase of NES behaviours.

Interventions to control anxiety and stress seem to contribute to the control of some of the behaviours of the syndrome ${ }^{38}$, and, consequently, should be considered in the prevention and treatment of the syndrome ${ }^{35}$, particularly among students.

This is the first time that three domains of the psychological state were evaluated simultaneously in relation to NES. The DASS-21 rapid assessment instrument was used, which reaffirmed the previously described associations, revealing a suitable and rapid tool to comprehensively assess the emotional disturbances of individuals at risk of NES.

A particular aspect of this research was to evaluate NES in students that work out of school time. A large proportion of participants worked at least four hours a day before or after studying. Although no significant association was found between this condition and the syndrome, a tendency $(p=0.068)$ was observed for 
evening students who work to present a lower NEQ score than students of the same period who did not work. This suggested relation, if eventually evaluated by other studies, would indicate that studying and working may have an unexpected protective effect against NES behaviours in relation to studying alone. Such phenomenon could be an interesting hypothesis to be investigated about this syndrome.

Some limitations of this research should be emphasised. All the data were obtained from self- administered questionnaires and, thus, may present flaws inherent to this type of instrument, derived from the misunderstanding of the questions or inaccuracy in the answers. Only one of the instruments available for evaluation of NES was used. NEQ is a scanning tool and, in isolation, does not allow definitive diagnosis of the syndrome. Finally, the population studied comes from a single higher education institution, and the results found may not be representative of the reality of other universities or colleges.

\section{CONCLUSION}

Evidence of high prevalence of Night Eating Syndrome among university students of a Brazilian private higher education institution was found. In addition, there was an association between the behaviours of the syndrome and the severity of symptoms of depression, anxiety, and stress among these students.

\section{Acknowledgements}

The authors wish to acknowledge the help of Elanny de Oliveira, Poliana Simões Lyra.

\section{REFERENCES}

1. Erskine HE, Whiteford HA, Pike KM. The global burden of eating disorders. Curr Opin Psychiatry. 2016; 29(6):346-53. DOI: http://dx.doi.org/10.1097/YCO.0000000000000276

2. American Psychiatric Association. Diagnostic and Statistical Manual of Mental Disorders, Fifth Edition (DSM-5). Arlington: American Psychiatric Association, 2013.

3. Cleator J, Abbott J, Judd P, Sutton C, Wilding JPH. Night eating syndrome: implications for severe obesity. Nutr Diabetes. 2012; 2(9):e44. DOI: http://dx.doi.org/10.1038/nutd.2012.16

4. Birketvedt GS, Florholmen J, Sundsfjord J, Osterud B, Dinges D, Bilker W, et al. Behavioral and neuroendocrine characteristics of the night-eating syndrome. JAMA. 1999; 282(7):657-63. DOI: http://dx.doi.org/10.1001/jama.282.7.657

5. Allison KC, Ahima RS, O'Reardon JP, Dinges DF, Sharma V, Cummings DE, et al. Neuroendocrine profiles associated with energy intake, sleep, and stress in the night eating syndrome. J Clin Endocrinol Metab. 2005; 90(11):6214-7. DOI: http://dx.doi.org/10.1210/jc.2005-1018

6. Goel N, Stunkard AJ, Rogers NL, Van Dongen HP, Allison KC, O'Reardon JP, et al. Circadian rhythm profiles in women with night eating syndrome. J Biol Rhythms. 2009; 24(1):85-94. DOI: http://dx.doi.org/10.1177/0748730408328914

7. Allison KC, Lundgren JD, O'Reardon JP, Geliebter A, Gluck ME, Vinai P, et al. Proposed diagnostic criteria for night eating syndrome. Int J Eat Disord. 2010; 43(3):241-7. DOI: http://dx.doi.org/10.1002/eat.20693

8. Stunkard AJ, Grace WJ, Wolff HG. The night-eating syndrome; a pattern of food intake among certain obese patients. Am J Med. 1955; 19(1):78-86. DOI: http://dx.doi.org/10.1016/0002-9343(55)90276-X

9. Marshall HM, Allison KC, O'Reardon JP, Birketvedt G, Stunkard AJ. Night eating syndrome among nonobese persons. Int J Eat Disord. 2004; 35(2):217-22. DOI: http://dx.doi.org/10.1002/eat.10241

10. Rand CS, Macgregor AM, Stunkard AJ. The night eating syndrome in the general population and among postoperative obesity surgery patients. Int J Eat Disord. 1997; 22(1):65-9. DOI: http://dx.doi.org/10.1002/(SICI)1098-108X(199707)22:1<65::AID-EAT8>3.0.CO;2-0

11. Zwaan M, Müller A, Allison KC, Brähler E, Hilbert A. Prevalence and correlates of night eating in the German general population. PLoS One. 2014; 9(5):e97667. DOI: http://dx.doi.org/10.1371/journal.pone.0097667

12. Opolski M, Chur-Hansen A, Wittert G. The eating-related behaviours, disorders and expectations of candidates for bariatric surgery. Clin Obes. 2015; 5(4):165-97. DOI: http://dx.doi.org/10.1111/cob.12104

13. Kouidrat Y, Amad A, Lalau JD, Loas G. Eating disorders in schizophrenia: implications for research and management. Schizophr Res Treatment. 2014;2014:791573. DOI: http://dx.doi.org/10.1155/2014/791573 
14. Olbrich K, Mühlhans B, Allison KC, Hahn EG, Schahin SP, Zwaan M. Night eating, binge eating and related features in patients with obstructive sleep apnea syndrome. Eur Eat Disord Rev. 2009; 17(2):1207. DOI: http://dx.doi.org/10.1002/erv.908

15. Nelson MC, Story M, Larson NI, Neumark-Sztainer D, Lytle LA. Emerging adulthood and college-aged youth: an overlooked age for weight-related behavior change. Obesity (Silver Spring). 2008; 16(10):220511. DOI: http://dx.doi.org/10.1038/oby.2008.365

16. Quick VM, Byrd-Bredbenner C. Disturbed eating behaviours and associated psychographic characteristics of college students. J Hum Nutr Diet. 2013; 26(Suppl.1):53-63.

DOI: http://dx.doi.org/10.1111/jhn.12060

17. Striegel-Moore RH, Franko DL, Thompson D, Affenito S, Kraemer HC. Night eating: prevalence and demographic correlates. Obesity (Silver Spring). 2006; 14(1):139-47. DOI: http://dx.doi.org/10.1038/oby.2006.17

18. Gaultney JF. The prevalence of sleep disorders in college students: impact on academic performance. J Am Coll Health. 2010; 59(2):91-7. DOl: http://dx.doi.org/10.1080/07448481.2010.483708

19. Storrie K, Ahern K, Tuckett A. A systematic review: Students with mental health problems - a growing problem. Int J Nurs Pract. 2010; 16(1):1-6. DOI: http://dx.doi.org/10.1111/j.1440-172X.2009.01813.x

20. Nolan LJ, Geliebter A. "Food addiction" is associated with night eating severity. Appetite. 2016; 98:89-94. DOI: http://dx.doi.org/10.1016/j.appet.2015.12.025

21. Meule A, Allison KC, Platte P. A German version of the Night Eating Questionnaire (NEQ): psychometric properties and correlates in a student sample. Eat Behav. 2014; 15(4):523-7. DOI: http://dx.doi.org/10.1016/j.eatbeh.2014.07.002

22. Runfola CD, Allison KC, Hardy KK, Lock J, Peebles R. Prevalence and clinical significance of night eating syndrome in university students. J Adolesc Health. 2014; 55(1):41-8. DOI: http://dx.doi.org/10.1016/j.jadohealth.2013.11.012

23. Elsadek AM, Hamid MS, Allison KC. Psychometric characteristics of the Night Eating Questionnaire in a Middle East population. Int J Eat Disord. 2014; 47(6):660-5. DOI: http://dx.doi.org/10.1002/eat.22285

24. Sevincer GM, Ince E, Taymur I, Konuk N. Night Eating Syndrome Frequency in University Students: Association with Impulsivity, Depression, and Anxiety. Klinik Psikofarmakol Bülteni 2016; 26(3):238-47. DOI: https://dx.doi.org/10.5455/bcp.20160322093750

25. O'Reardon JP, Stunkard AJ, Allison KC. Clinical trial of sertraline in the treatment of night eating syndrome. Int J Eat Disord. 2004;35(1):16-26. DOI: https://dx.doi.org/10.1002/eat.10224

26. Harb ABC, Caumo W, Hidalgo MPL. Translation and adaptation of the Brazilian version of the Night Eating Questionnaire. Cad Saúde Publica. 2008; 24(6):1368-76. DOI: http://dx.doi.org/10.1590/S0102-311X2008000600017

27. Henry JD, Crawford JR. The short-form version of the Depression Anxiety Stress Scales (DASS-21): construct validity and normative data in a large non-clinical sample. Br J Clin Psychol. 2005 Jun;44(Pt 2):227-39. DOI: http://dx.doi.org/10.1348/014466505X29657

28. Vignola RC, Tucci AM. Adaptation and validation of the depression, anxiety and stress scale (DASS) to Brazilian Portuguese. J Affect Disord. 2014; 155:104-9. DOI: http://dx.doi.org/10.1016/j.jad.2013.10.031

29. Allison KC, Lundgren JD, O'Reardon JP, Martino NS, Sarwer DB, Wadden TA, et al. The Night Eating Questionnaire (NEQ): psychometric properties of a measure of severity of the Night Eating Syndrome. Eat Behav. 2008; 9(1):62-72. DOI: http://dx.doi.org/10.1016/j.eatbeh.2007.03.007

30. Lovibond SH, Lovibond PF. Manual for the Depression Anxiety Stress Scales, 4th ed. Sydney: Psychology Foundation, 2004.

31. Lundgren JD, Allison KC, O'Reardon JP, Stunkard AJ. A descriptive study of non-obese persons with night eating syndrome and a weight-matched comparison group. Eat Behav. 2008;9(3):343-51. DOI: http://dx.doi.org/10.1016/j.eatbeh.2007.12.004

32. Kucukgoncu S, Tek C, Bestepe E, Musket C, Guloksuz S. Clinical features of night eating syndrome among depressed patients. Eur Eat Disord Rev. 2014; 22(2):102-8. DOI: http://dx.doi.org/10.1002/erv.2280

33. Thompson SH, DeBate RD. An exploratory study of the relationship between night eating syndrome and depression among college students. J Coll Stud Psychother. 2010; 24:39-48. DOI: http://dx.doi.org/10.1080/87568220903400161

34. Colles SL, Dixon JB, O'Brien PE. Night eating syndrome and nocturnal snacking: association with obesity, binge eating and psychological distress. Int J Obes (Lond). 2007; 31(11):1722-30. DOI: http://dx.doi.org/10.1038/sj.ijo.0803664 
35. Vander Wal JS. Night eating syndrome: a critical review of the literature. Clin Psychol Rev. 2012; 32(1):49-59. DOI: http://dx.doi.org/10.1016/j.cpr.2011.11.001

36. Wichianson JR, Bughi SA, Unger JB, Spruijt-Metz D, Nguyen-Rodriguez ST. Perceived stress, coping and night-eating in college students. Stress and Health 2009; 25(3):235-40. DOI: http://dx.doi.org/10.1002/smi.1242

37. Napolitano MA, Head S, Babyak MA, Blumenthal JA. Binge eating disorder and night eating syndrome: psychological and behavioral characteristics. Int J Eat Disord. 2001; 30(2):193-203. DOI: http://dx.doi.org/10.1002/eat.1072

38. Pawlow LA, O'Neil PM, Malcolm RJ. Night eating syndrome: effects of brief relaxation training on stress, mood, hunger, and eating patterns. Int J Obes Relat Metab Disord. 2003; 27(8):970-8. DOI: http://dx.doi.org/10.1038/sj.ijo.0802320

\section{Resumo}

Introdução: Estudantes universitários estão expostos a muitos fatores relacionados à Síndrome do Comer Noturno (SCN), um transtorno alimentar que pode estar associado à obesidade.

Objetivo: Determinar a prevalência da SCN entre estudantes de uma universidade brasileira e avaliar a associação de comportamentos da síndrome a fatores emocionais, biológicos e ambientais.

Método: Estudo transversal realizado com 200 estudantes de instituição de ensino superior privada localizada na cidade de Juazeiro do Norte, Ceará, Brasil. A SCN foi avaliada por meio do Night Eating Questionnaire (NEQ), considerando-se o escore NEQ $\geq 25$ como valor de corte para indicação da síndrome. Sintomas depressivos, de ansiedade e de estresse foram avaliados por meio do questionário Depression Anxiety Stress Scales (DASS-21). Informações adicionais foram coletadas sobre os participantes (sexo, idade, peso, altura); seu status acadêmico (tipo de curso, período, série); e seu status empregatício (se o participante trabalha ao menos $4 \mathrm{~h}$ diárias além de estudar).

Resultados: 30 participantes (15\%) apresentaram o escore NEQ $\geq 25$, indicativo da SCN. Não houve associação entre o escore NEQ e as variáveis: sexo, estado nutricional, trabalho, curso matriculado, período de estudo e série cursada. Foi observada associação entre o escore NEQ e a severidade de depressão $(p=0,0001)$, de ansiedade $(p=0,0001)$ e de estresse $(p=0,0218)$.

Conclusão: Foram encontradas evidências de alta prevalência da $S C N$ entre estudantes universitários brasileiros e verificou-se associação dos comportamentos da síndrome com sintomas depressivos, de ansiedade e de estresse.

Palavras-chave: transtornos da alimentação e da ingestão de alimentos, estudantes, depressão, ansiedade, estresse psicológico

${ }^{\odot}$ The authors (2017), this article is distributed under the terms of the Creative Commons Attribution 4.0 International License (http://creativecommons.org/licenses/by/4.0/), which permits unrestricted use, distribution, and reproduction in any medium, provided you give appropriate credit to the original author(s) and the source, provide a link to the Creative Commons license, and indicate if changes were made. The Creative Commons Public Domain Dedication waiver (http://creativecommons.org/publicdomain/ zero/1.0/) applies to the data made available in this article, unless otherwise stated. 